\title{
Deposits in utilized Icelandic high-temperature systems
}

Halldór Ármannsson ${ }^{1, *}$

${ }^{1}$ ÍSOR, Iceland Geosurvey, Grensásvegur 9, 108 Reykjavík. Iceland

\begin{abstract}
The most common scales in 7 utilized Icelandic hightemperature geothermal systems are calcite, amorphous silica, magnesium silicates, iron silicates, aluminium silicates and metal sulphides. They are mostly controlled by adjustment of temperature and pressure although chemical inhibition may be preferred due to production capacity. Reaming of wells by drilling and physical removal from surface equippment or acid cleaning may be needed.
\end{abstract}

\section{Introduction}

Seven utilized high temperature areas are considered [1] (Figure 1).

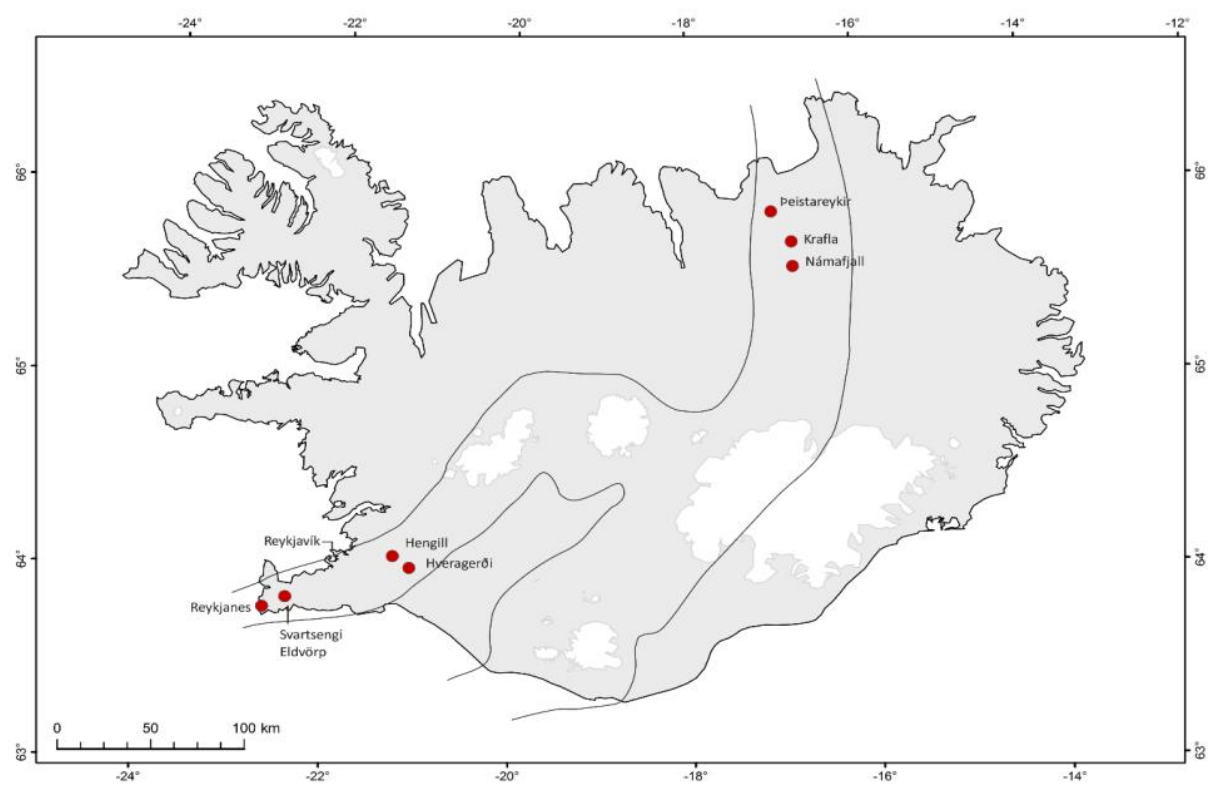

Fig. 1. High temperature geothermal areas in Iceland considered in this study.

\footnotetext{
*Corresponding author: $\underline{\mathrm{h} @ \text { isor.is }}$
} 
An earlier review concluded that calcium carbonate, aluminium silicate and amorphous silica scales are problematic in direct utilization upon cooling of high temperature waters, but iron-and magnesium silicates and metal sulphides in saline high-temperature waters [2]. Here additional knowledge is considered.

\section{Individual areas}

\subsection{Reykjanes}

The Reykjanes geothermal area is situated in the extreme SW of Iceland (Figure 1). HSOrka runs a $100 \mathrm{MW}_{\mathrm{e}}$ capacity power plant in the area. Magmatic activity provides a heat source for the geothermal system. Frequent, but generally small, earthquakes cause movements on fractures and maintain good permeability. In the 4659 m deep Well IDDP 2 a temperature of $427^{\circ} \mathrm{C}$ and a pressure of 340 bar have been logged at the bottom but no fluid has been retrieved from it as yet. Fresh water and seawater are the source of the geothermal fluid having in earlier time either been present alternately or as a mixture [1]. The most important deviations from sea water chemistry are magnesium and sulphate depletion and increases in silica, potassium and calcium concentrations all to be expected at high temperatures. The gas concentrations show $\mathrm{CO}_{2}$ to be the major gas but $\mathrm{H}_{2} \mathrm{~S}$ concentrations are relatively low compared to those of fluids from many other geothermal areas in Iceland. Downhole scales of iron-magnesium-silicates have formed. Metal sulfides with high concentrations of precious metals have been precipitated at the wellhead in producing wells [1]. At $>16$ bar a sulphides, such as galena, sphalerite, wurtzite, troilite, pyrite, chalcocite, chalcopyrite, and bornite, are the predominant deposits, but at lower pressures and down to the amorphous silica saturation pressure iron silicates are most abundant after which amorphous silica predominates. The sulphides can be chemically inhibited and also the iron silicates although their deposition can be prevented by keeping the wellhead pressure above 16 bar a, and the amorphous silica deposition by keeping the separator pressure above the saturation pressure of amorphous silica.

\subsection{Svartsengi-Eldvörp}

The Svartsengi geothermal system is situated within the Grindavík fissure swarm on the Reykjanes peninsula (Figure 1). The Eldvörp geothermal field is $7 \mathrm{~km}$ to the west from Svartsengi. HS-Orka runs a $75 \mathrm{MW}_{\mathrm{e}}$ power plant, and a $190 \mathrm{MW}_{\mathrm{t}}$ space heating plant in the area. The reservoir was liquid-dominated when production started. Like at Reykjanes the water is enriched in $\mathrm{SiO}_{2}, \mathrm{Ca}^{2+}$ and $\mathrm{K}^{+}$but depleted in $\mathrm{SO}_{4}^{-2}$ and $\mathrm{Mg}^{+2}$ compared to seawater due to base-exchange, hydrolysis and redox reactions. The gas is predominantly $\mathrm{CO}_{2}$. Silica and calcite deposits on the turbine blades in the power plant have caused problems. A solution to this problem was to wash the steam with fluid from other wells [3]. During the early years of production calcite scaling was a considerable problem and the wells were reamed using drill rigs every second year. In the mid-1980s these deposits stopped forming probably due to a small increase in the enthalpy of the well fluids

Magnesium silicate precipitates from freshwater heated with steam in heat exchangers, which increases with high temperature and $\mathrm{pH}$ are a problem. To prevent these $\mathrm{pH}$ is controlled by injecting $\mathrm{CO}_{2}$ into the deaerated fresh water. The separator and brine pipe pressure is kept high to prevent silica scaling [3]. 


\subsection{Hengill}

The Hengill area, about $30 \mathrm{~km}$ east of Reykjavík covers about $100 \mathrm{~km}^{2}$ according to results of geophysical measurements. The three fields connected to the Hengill central volcano (Nesjavellir, Hellisheidi and Hverahlíd), and the one connected to the Hrómundartindur volcanic system (Ölkelduháls) constitute the Hengill geothermal system. All three are seismically active. Reykjavík Energy runs a $120 \mathrm{MW}_{\mathrm{e}}$ power plant and a $300 \mathrm{MW}_{\mathrm{t}}$ space heating plant in Nesjavellir, and a $300 \mathrm{MW}_{\mathrm{e}}$ power plant and a $133 \mathrm{MW}_{\mathrm{t}}$ space heating plant in Hellisheidi.

The present conceptual model indicates a strong likelihood for at least two, and possibly as many as four, distinct upflow zones of fluid at temperatures $>300^{\circ} \mathrm{C}$ [4]. The heat sources for geothermal activity at Hengill are associated with upward bulging of a general sheeted dyke complex and its local extensions. The main aquifer found in the Nesjavellir producing wells is at 1000 to $1500 \mathrm{~m}$ depth and the aquifer temperature is in the range 260 $-290^{\circ} \mathrm{C}$, but a temperature of $>380^{\circ} \mathrm{C}$ has been encountered in one well. Pressures up to about 150 bar have been recorded at 2000-2100 m depth at Nesjavellir but at Hellisheidi temperatures in excess of $300^{\circ} \mathrm{C}$ and pressures above 150 bar have been logged at 2400 $2500 \mathrm{~m}$ depth. Deaerated water from Nesjavellir was originally allowed to mix with the geothermal water in Reykjavík, but heavy magnesium silicate scaling took place in the pipeline system. A thorough study was initiated to determine whether it would be possible to mix the two types of water without scaling [4]. The results showed that the distribution system had to be modified to keep the waters separated at all times. Deposits from the separated borehole water form on the inner surface of the heat exchanger heating freshwater at the power plant. To remove the deposits, steel balls are placed in the current to pulverize them.

Hellisheidi waters plot close to the mineral-gas equilibrium curve for the redox reactions involving pyrite, pyrrhotite, $\mathrm{H}_{2} \mathrm{~S}$ and $\mathrm{H}_{2}$, yet systematically below the equilibrium curve. Hellisheidi waters are considerably anhydrite undersaturated., and calcite deposition is considered unlikely.

\subsection{Hveragerdi}

The Hveragerdi area is located about $50 \mathrm{~km}$ east of Reykjavík (Figure 1). Reykjavík Energy utilizes about $170 \mathrm{TJ}$ for a space heating plant and greenhouses in the area.. The area is considered as having reached a final stage of a long term cooling process [5]. The highest temperature $232^{\circ} \mathrm{C}$ has been recorded in the northernmost well, and the highest pressure $88 \mathrm{bar}$ at $1017 \mathrm{~m}$ depth. A temperature reversal is observed in all wells and the maximum temperature and the depth at which it is observed decreases from NE to SW indicating that this is the direction of the flow and that the general flow is upwards suggesting a lateral flow from the central parts of the Hengill geothermal area. Discharges from most springs are $\mathrm{Na}-\mathrm{HCO}_{3}$ waters, probably steam-heated $\mathrm{Na}-\mathrm{Cl}$ water, but water from deep aquifers in wells are Na$\mathrm{Cl}$ waters. Gaseous compounds make up only about $0.02 \%$ of the total volume of the fumarole steam, considerably less than observed in most other high-temperature geothermal fields in Iceland probably due to the relatively low temperature. The gas chemistry of this field is also characterised by low concentrations of $\mathrm{H}_{2} \mathrm{~S}$ and $\mathrm{H}_{2}$ compared to the neighbouring fields of Nesjavellir and Hellisheidi [1]. The major utilization problem in Hveragerdi has been calcite scaling. Flashing results in supersaturation with respect to calcite. The narrowness of the early wells caused them to be blocked quite quickly and they had to be reamed every $6-7$ months. Silica scaling had not been expected at above $80^{\circ} \mathrm{C}$ but turned out to set in at $95^{\circ} \mathrm{C}$ precipitating scales, that turned out to be aluminium silicates, in the distribution system and in heat exchangers that had been installed in each house and had to be cleaned by wire brushing every six months [2] The space heating system used a mixture of 
geothermal water and fresh water heated by direct injection of steam causing magnesium silicate deposition but later just heated water reducing the deposition [2]. Recently deposits that proved to be siderite have been observedin fluid from one well, presumable caused by iron from corrosion of pipes [6]

\subsection{Námafjall}

Mt Námafjall is a tindar about $5 \mathrm{~km}$ south of the southern margin of the Krafla caldera and $5 \mathrm{~km}$ east of Lake Mývatn (Figure 1). The active geothermal area is about $5 \mathrm{~km}^{2}$ and warm water runoff to Lake Mývatn is about $11 \mathrm{~m}^{3} / \mathrm{s}$. A resistivity anomaly extends it to about 20 $\mathrm{km}^{2}$ at $800-1000 \mathrm{~m}$ depth. Landsvirkjun runs a $3 \mathrm{MW}_{\mathrm{e}}$ power station in the area and Reykajhlíd Heating Company utilizes 50-60 TJ for a space heating plant. The permeability is fracture dominated. The borehole fluid is dilute and the TDS in the deep reservoir around $0.1 \%(1 \mathrm{~g} / \mathrm{kg})$ and $\mathrm{pH}$ 7-8. Chloride and sulfate are the main anions, but their concentrations vary. The gas concentrations in the steam are generally low, $0,3-0,5 \mathrm{w} \%$. About $50 \%$ of the gas is $\mathrm{H}_{2} \mathrm{~S}$, and the $\mathrm{H}_{2}$ concentration is high. Originally the heating plant used direct steam injection into cold groundwater causing magnesium silicate scaling but with a heating plant first using warm groundwater but then cold springwater and injecting steam into the hot water to keep down the $\mathrm{pH}$ and to scavenge oxygen leaking through the polybutelene pipelines has reduced the scaling [1].

\subsection{Krafla}

The Krafla high temperature geothermal system lies in the northern part of the spreading zone, within the caldera of the Krafla central volcano. Landsvirkjun (The National Power Company) runs a $60 \mathrm{MW}_{\mathrm{e}}$ power station in the area. Volcanic activity is extensive, the last eruptive period lasting from 1975 to 1984 during which 9 eruptions took place. The geothermal area trends WNW-ESE across the caldera, transversally to the fissure swarms but parallel with the spreading direction most likely due to dilatation in relation to stationary intrusive activity producing centrally located heat sources. The fluids contain dilute waters of close to neutral $\mathrm{pH}$. Three separate upflow channels for geothermal fluids have been identified, the major one associated with the volcanic Hveragil fissure. The recharge is essentially local in origin according to isotope ratios although some subareas may be recharged from far south of the field [1]. Acidity has been associated with magmatic activity in the Krafla volcanic system 1975-1984 which manifested itself in excess gas in the geothermal system and deposition of iron sulphides, iron silicates, iron oxides and silica [1]. Acid fluids from several wells are distributed all over the area but the common denominator is that all the wells are deep [1]. At least two of these wells have hit magma at a relatively shallow depth. The first Iceland Deep Drilling Project well (IDDP01) was drilled in 2009, hit magma at about $2100 \mathrm{~m}$ depth and drilling was stopped. A temperature in excess of $450^{\circ} \mathrm{C}$ was observed at the wellhead. The main scaling problems in the surface equipment were due to dissolved silica and sulphur in the superheated steam [1]. A presssure up to $160-165$ bar has been observed at $2070 \mathrm{~m}$ depth. The $\mathrm{pH}$ of the condensate obtained from the well at $440^{\circ} \mathrm{C}$ was between 2 and 3 and the main anion chloride [1]. Where volcanic gas affects the system $\mathrm{FeS}_{2}$ (pyrite) and $\mathrm{FeS}$ (pyrrhotite) are the most common sulphide deposits. Such scales along with iron silicates were observed in several wells during the Krafla fires 1975-1984. During the early stages of production from the Krafla field calcite scaling was observed in some shallow wells and reaming with a drill rig was used to control the scaling. Tests in Krafla proved Nalco $1340 \mathrm{HP}$ to be the most effective inhibitor of calcite [1] and it has been used with success making reaming unnecessary 


\subsection{Theistareykir}

Theistareykir is a high-temperature geothermal area in NE-Iceland (Figure 1), probably. of $25-30 \mathrm{~km}^{2}$ extent [1]. Landsvirkjun (The National Power Company) runs a $90 \mathrm{MW}_{\mathrm{e}}$ power station there. The main features in the geology are an ESE-WNW trending geothermal area and a heat source astride a N-S tectonic structure connected to an active central volcano. The youngest lava is about 2700 year old. The bedrock temperature in nine wells exceeded $300^{\circ} \mathrm{C}$, three $280-300^{\circ} \mathrm{C}$, and six $200-250^{\circ} \mathrm{C}$ The maximum temperature recorded is $380^{\circ} \mathrm{C}$. Downhole pressures from 125 to 223 bar have beeen recorded. The fluids are dilute with those from the hotter wells being $\mathrm{Na}-\mathrm{Cl}$ but those from the cooler ones $\mathrm{Na}-\mathrm{HCO}_{3}$ waters. The origin of the fluid is apparently far to the south and it is probably quite old. The aquifer concentrations of $\mathrm{H}_{2} \mathrm{~S}$ and $\mathrm{H}_{2}$ indicate that they are buffered by pyrite and pyrrhotite Deposits have not been observed but the saturation index calculated at 100 to $287^{\circ} \mathrm{C}$ shows that the fluid from the coolest well remains undersaturated with respect to amorphous silica but calcite scaling is likely to take place at a boiling temperature higher than $198^{\circ} \mathrm{C}$ and amorphous silica scaling in the hottest well. If the fluid is boiled below $178^{\circ} \mathrm{C}$, silica scaling may take place, and calcite scaling at temperatures higher than $220^{\circ} \mathrm{C}$ and both may be problematic in intermediate wells [1].

\section{Conclusions}

Deposits have been a problem in the utilization of Icelandic geothermal fluidsn but by proper engineering the problems have been solved successfully. Sulphide and iron silicate scales have been observed in hot, saline fluids and where volcanic gas has been present. Silica and aluminium silica scales are formed upon cooling of hot fluids and are often problematic especially in surface equipment, and calcite scales are problematic where fluids of $<260^{\circ} \mathrm{C}$ boil adiabatically. In most cases scales can be controlled by keeping temperature and pressure within limits but this may limit the production capacity of the wells. Traditionally reaming with a drill rig has been the method to remove deposits but prevention of deposition using inhibitors is the present method. Scales in equipment are usually removed by physical methods although acid washing has been employed for surface equipment and downhole.

\section{References}

1. H. Ármannsson. Appl. Geochem., 66, 14-6 (2016)

2. H.Kristmannsdóttir,. Geothermics, 18, 181-190 (1989).

3. G. Thorolfsson. Proc. World Geothermal Congress 2005 Antalya, Turkey, 24-29 April 2005, 7 (2005)

4. G Björnsson,Orkuveita Reykjavíkur (Report No. 2007-3, 65 (2007)

5. T. Hauksson, S. Thórhallson, E. Gunnlaugsson, A. Albertsson, Proc. World Geoth. Congress 1995, Firenze, Italy, 2487-2490 (1995)

6. A. Barja. MSc Thesis. Iceland School of Energy, Reykjavík University, 60 (2014) 